\title{
Restoration for Whom, by Whom? A Feminist Political Ecology of Restoration ${ }^{\text {a }}$
}

\author{
Marlène Elias, Deepa Joshi, and Ruth Meinzen-Dick
}

\begin{abstract}
The UN Decade on Ecosystem Restoration (2021-2030) frames restoration as a momentous nature-based solution for achieving many of the ecological, economic, and social objectives outlined in the Sustainable Development Goals. Yet, a critical void lies at the heart of this agenda: the lack of attention to social and political dimensions of nature and restoration initiatives. At this critical juncture, urgent attention is needed to the power and politics that shape the values, meanings, and science driving restoration; and to the uneven experiences of these processes as national restoration pledges touch down in diverse and unequal contexts. In this introduction to the special issue on "Restoration for Whom, by Whom?", we critically examine the social inclusivity of restoration agendas, policies, and practices as these unfold across ecological and geographic scales. We argue that feminist political ecology (FPE), with its focus on gendered power relations, scale integration, and historical awareness, and its critique of the commodification of nature, offers a valuable lens through which to examine the socio-political and economic dynamics of restoration. Taking an FPE perspective, we elucidate how the ten papers comprising the special issue challenge mainstream narratives of environmental sustainability and suggest more grounded and nuanced ways forward for inclusive restoration initiatives. In conclusion, we highlight the urgency of addressing the systemic fault lines that create exclusions in restoration policies and practice; and the need to legitimize the plural voices, values, situated knowledges, and paths to sustainably transform degraded landscapes.
\end{abstract}

Keywords: Feminist political ecology, gender, restoration, social inclusion, sustainability

- Transforming degraded landscapes requires tackling not just biophysical, but equally the social and political dimensions of restoration.

- Taking a feminist political ecology perspective, this introduction shows how the ten papers comprising the special issue on "Restoration for Whom, by Whom" suggest ways forward for more inclusive restoration interventions.

- Unequal power relations between the state and local communities, within communities, and within households shape how restoration priorities are set, whose knowledge counts, and how rights to resources and benefits are perceived and distributed.
- Restoration initiatives should consider the interlocking nature of ecological change and the socio-political histories that shape land degradation, contemporary rights to resources, and the values different actors place upon resource management (including restoration) options.

- Ecological restoration comprises trade-offs among a mosaic of land uses and users at different scales and requires attention to the way global interests and the global restoration agenda frame national, landscapescale, and local restoration initiatives.
Cince the 1972 United Nations Conference on the $\checkmark$ Human Environment (UNCHE), habitat loss, defaunation, carbon emissions and global warming have spiked despite the proliferation of global environmental

2 This open access article is distributed under the terms of the CC-BYNC-ND license (http://creativecommons.org/licenses/by-nc-nd/3.0) and is freely available online at: http://er.uwpress.org

Ecological Restoration Vol. 39, Nos. 1-2, 2021

ISSN 1522-4740 E-ISSN 1543-4079

(O2021 by the Board of Regents of the University of Wisconsin System. agreements, national environmental laws and policies, and voluntary environmental codes of conduct for the private sector (Collard and Dempsey 2020). Inscribed amid these high level environmental initiatives, the UN Decade on Ecosystem Restoration (2021-2030) reflects and accelerates international and national commitments to "scale up the restoration of degraded and destroyed ecosystems as a proven measure to fight the climate crisis and enhance food security, water supply and biodiversity" (UNEP 2019). This global initiative frames restoration as a momentous shift to nature-based solutions for achieving many of the 
ecological, economic, and social objectives outlined in the Sustainable Development Goals (SDGs). Visually and conceptually expressed as "tree-planting" and other "greening" approaches, the restoration agenda offers a compelling vision to unite the global community. Yet, a critical void lies at the heart of this agenda: the lack of attention to social and political dimensions of restoration.

The Society for Ecological Restoration (SER) Primer on Ecological Restoration provides a widely accepted definition of ecological restoration as: "the process of assisting the recovery of an ecosystem that has been degraded, damaged or destroyed" (SER 2004, 3). While opening up the possibility for creative human practice in assisting such recovery, the Primer is conspicuously silent on issues related to human well-being, power and inclusiveness in restoration. Fifteen years later, SER's second edition of the "International Principles and Standards for the Practice of Ecological Restoration" (the Standards) attempts to more explicitly integrate socio-economic and cultural factors into the frameworks underpinning restoration initiatives, including through the addition of a "Social Benefits Wheel" to help track progress towards social development goals and targets (Gann et al. 2019). Despite their drawbacks discussed below, in drawing attention to local ecological knowledge, well-being, and distributional issues related to restoration, the Standards begin to acknowledge that the ecological resilience of the planet is not disassociated from the well-being of its people.

Still, the predominance of natural sciences in restoration has encouraged largely exclusionary interpretations of sustainability and technocratic solutions which narrowly focus on the biophysical (Higgs 2003, Martin 2017). Moreover, despite some examples of bottom-up and participatory restoration processes (e.g., Lee et al. 2021), the ambitions of doing restoration "at scale" have given impetus to top-down and standardized approaches. When gender equality and social inclusion are written into restoration agendas, policies, and practices, current restoration interventions try, at best, to fit in (i.e., "integrate") sociopolitical dimensions in what is essentially a neoliberal conservation agenda (Collard and Dempsey 2020). That is, restoration initiatives are steeped in the logic of "green development", or development that "cultivates the natures that support thriving economies" (Collard et al. 2015). In this narrative, human-nature relations are depoliticized and disembodied in overly simplistic framings. In all of this, the power and politics that shape the values, meanings, nature, and experiences of restoration remain peripheral, and the outcomes of restoration initiatives, at best, are uneven as restoration pledges touch down in diverse and unequal contexts. This substantiates Li's (2017) claim that the stories we tell ourselves and others around the problem of development and environment, and the technical solutions we offer (as restoration), require significant unpacking and complexification.
In this special issue, we examine how nature-people interrelations are interpreted and translated into practice. We ask: who sets restoration agendas and for whom, why and how, and what other political and economic interests and mandates influence these agendas? In so doing, we examine if and how plural, unequal local voices and knowledge systems are valued or ignored, and the influence they hold (or not) in initiatives to restore what are designated as "degraded landscapes". We closely analyze restoration narratives, policies and practices to assess if they transform or instead reinforce persisting institutional practices, tenure regimes, norms and boundaries that impact gender inequality and social inclusion. In doing so, we reflect on the narratives that commodify nature that underpin the "politics in and of restoration" (Light 1994, Perry 1994, Light and Higgs 1996; compare with popular accounts that offer a more inclusive and holistic understanding of restoration, e.g., Mills 1995, Wilson 2019). Our aim is to prompt critical reflection that can open new avenues for meaningful engagement with issues of power and justice in restoration, to challenge the assumptions and discourses that (re)produce the status quo, and suggest ways forward for more political, inclusive agendas.

The papers comprising this issue bring together perspectives of academics and practitioners, NGOs and government actors working across disciplines, socio-ecological systems, and scales. In this introductory paper, we adopt a feminist political ecology (FPE) perspective to challenge mainstream narratives of ecological restoration. We draw out the contributions an FPE analysis can make to the field as an open and discursive approach rather than an overly prescriptive tool for guiding restoration initiatives. In surfacing key socio-political processes and pitfalls of restoration initiatives, the case studies presented in this special issue then offer more contextually grounded, tangible entry points for an inclusive sustainability in and through restoration.

In the section below, we begin by defining FPE and its relevance to the field of restoration. We then argue that a focus on (gendered) power relations, historical awareness, and scale integration - three pillars of FPE-are particularly relevant for illuminating the dynamics of social inclusion in restoration. We conclude that much needs to change to address the systemic fault lines that create exclusions in restoration policies and practice, and to legitimize the plural voices, values, meanings and situated knowledges of what makes the environment or nature in order to sustainably transform degraded landscapes.

\section{A Feminist Political Ecology of Restoration}

Although social and economic justice are just as relevant to sustainability as ecological considerations, sustainability science predominantly focuses on biophysical processes 
(Scoones 2016). In contrast, political ecologists have long argued that environmental changes and challenges are not mere by-products of biophysical changes to the ecosystem; rather, the key drivers of environmental change are economic, political, and social (Haraway 1991). Political ecology brings to light the dynamics of "politicized environments" (Bryant 1998) by situating environmental change within the politics and power relations that mediate access, control, and management of environmental resources across spatial and temporal scales (Blaikie and Brookfield 1987, Forsyth 2003, Peet and Watts 2004).

Political ecology analyses have focused on the exchange networks of information, materials, and support through which diverse groups of people secure access to resources, negotiate resource use, or resist unfavorable policies (Zimmerer 2003). This includes understanding how values shape processes of scientific reasoning (Łapniewska 2016). Whereas neoliberal conservation agendas adopt a narrow interpretation of social inclusion and equity-e.g., those focused on the rhetorical participation of local communities or the mere "adding in and stirring" of women (Harding 1995) - political ecology analyses unearth the deep-rooted dimensions of inequality and exclusion in what are essentially socio-environmental economic crises. They explore the role of activism and social movements in creating political resistance, engendering alternative development, and shaping the fate of environmental resources (Perreault 2003, Bebbington et al. 2004, Rocheleau 2008). Such analyses demonstrate that the processes through which legitimate spaces are created for multiple and diverse framings of the environment are entirely different to being merely engaged in the implementation of technocratic conservation ideas and interventions of expert others (Pérez and Ceccon 2017).

Feminist political ecology (FPE) expands the meanings of both environmental justice and restoration by "placing the operations of gender-power relations on the analytical centre stage" (Clement et al. 2019). This conceptual lens shines light on how gender intersects with class, race, and other axes of power to shape economic, social, and cultural institutions and environmental management decisions. It explores how these axes of power are situated in intertwined histories of colonialism, patriarchy and capitalism, which impact the perceived legitimacy of knowledgeholders, their knowledge, and how it is produced (Sundberg 2017). A feminist perspective pays attention to the embodied everyday experiences of nature-human interrelations and how these are played out in different spatial contexts (Elmhirst 2011, Rocheleau 2015). It foregrounds the gendered impacts of the (re)distribution of labor, land, income, and other resources in dynamic environmental change processes (Carney and Watts 1990, Agarwal 1997, Harcourt and Nelson 2015) to identify new possibilities for transformative practices (Clement et al. 2019). Although not all papers included in this special issue are explicitly framed in an FPE perspective, they all engage with issues that figure centrally in political ecological analyses, such as the socio-political dimensions of environmental knowledge production and the social relations, values, and mandates driving conservation (Robbins 2004, Jones 2008). Sundberg (2017, 7 citing Elmhirst 2011) explains that while "political ecology owes an epistemological debt to feminist theory for the range of fresh perspectives it offers (...) the contributions of FPE tend to be assimilated into mainstream political ecology with little explicit acknowledgment." In drawing attention to gendered power relations, historical awareness, and scale integration - three pillars of FPE-we demonstrate below how FPE can offer important insight into social inclusions and exclusions in restoration to help resolve the longstanding impasse on environmental and social sustainability.

\section{Power Relations}

Political ecologists focus on how power relations mediate material, symbolic, and discursive struggles over natural resources, controlling labor, resources, gains and losses; conflicts and contestations; and how these play out spatially, as determined by broader political and economic framings of the environment (Hecht and Cockburn 1989, Kull 2004, Bassett and Peimer 2015). Unequal power relations occur at different scales and among different types of actors, such as between the state and local communities (Mansourian 2021, McElwee and Nghi 2021), within communities (Sen et al. 2021), and among members of a given group, such as within a household (Crossland et al. 2021). Feminist political ecologists examine these processes through a gender lens, drawing particular attention to the gendered asymmetries in what is counted as knowledge, rights, responsibilities, and decision-making (Elmhirst 2011). They recognize that gender interacts with other factors of social differentiation and marginalization, such as socio-economic status, age, and ethnicity or caste, to shape environmental management processes (Rocheleau et al. 1996, Harcourt and Nelson 2015). This allows understanding how access to natural resources and their environmental benefits are shaped in and between households, through individual experiences, collective action and social movements (Elmhirst 2011).

Since ecological restoration centers on a fundamental asset for agricultural communities-land-it holds great transformative potential, as well as very high risks. When land considered or classified as "wasted" becomes restored or "regenerated", it acquires material and other values that can result in local communities-and particularly their most marginalized members-being dispossessed of their rights to use, access and gain from this resource. For instance, Schroeder's (1999) influential study in the Gambia showed how donor interest in "environmental stabilization" supported men's agroforestry projects on lands that women had been using for their gardens. Given insecure tenure 
rights, women, who had been allocated lands for gardening by senior male landowners, faced the threat of eviction as the land gained appeal for growing men's trees. Similar concerns of women's displacement and exclusions have been expressed in the context of REDD+, as their access to land and trees is often insecure and mediated by male relatives (Peach Brown 2011, Khadka et al. 2014, Larson et al. 2015). Sen et al.s (2021) study of "restoration" of peri-urban lakes in Bengaluru, India illustrates similar displacement processes among fishers and pastoralists, while some original residents with clear land rights were able to benefit.

Such tenure considerations are fundamental to the success, sustainability, and equitability of restoration (Unruh 2008, Mansourian 2017, McLain et al. 2018). Djenontin et al.s $(2018,15)$ review of success factors for FLR in subSaharan Africa underscores "[T] he strong need to consider the political dimensions of natural resource management and governance, in which lie the conundrums of contested issues surrounding land and forest resources [Larson and Springer 2016]. These include close attention to challenges of property rights, land tenure security, local land-use practices, their regulations and customs. The findings reflect the central role of power relations in institutional issues-who supports an intervention/action, who does not; their motivations; their social status and therefore level of influence; ultimately, who wins, who loses, and how they react."

The SER Standards prescribe understanding, clarifying and securing tenure rights on lands to be restored (Gann et al. 2019), but fall short of addressing the power relations that critically underpin negotiations, competing claims to land, conflicts over land use, or deep-rooted gender inequalities in land ownership, access and use. In light of the power inequalities embedded in multi-actor relations in restoration, political ecology analyses demonstrate the need for rights-based approaches that integrate safeguards and conflict-resolution mechanisms, to pre-empt the dispossession of local people from their lands and livelihoods. These are especially urgent amid the current rush for rural land in the name of food security, reforestation, and climate change (Barr and Sayer 2012, Sijapati Basnett et al. 2017). Others call for a more transformative agenda, highlighting the socially embedded nature of land and the need to explicitly address the historical roots of injustices that have disenfranchised local people of their lands (Osmani 2010). They highlight that individual rights "as designed by development institutions and sanctioned by states, often only treat land as a natural resource, without recognizing that the meanings of land and water take shape in collective ways that are always unfinished" (Mollet and Kepe 2018). In this perspective, the formalization of land rights-although necessary to avoid further disenfranchisement-is couched within the same neoliberal logics, mechanisms and global architecture that have encouraged large-scale land transactions and green grabs (ibid).
Whereas secure land rights can incentivize community investments in restoration (e.g., Chhatre et al. 2012, Quisumbing and Kumar 2014), insecure rights to land and trees (which are often distinct-see Crossland et al. 2021, Kandel et al. 2021) can have the opposite effect. Tenure insecurity, prevalent among marginalized households and women, can disincentivize investments in land improvement or the planting and management of trees over which they may not have control in the long-term (Mukadasi and Nabalegwa 2007, Lovo 2016). From a social inclusion perspective, secure tenure has been shown to give landowners a voice and stronger negotiating position when it comes to multi-actor planning and implementation of restoration initiatives (Cronkleton et al. 2017, McLain et al. 2018).

Substantiating this claim, Kandel et al. (2021) demonstrate that pre-existing asymmetries in land rights can underpin social exclusions in the context of restoration initiatives. In their case study in Northeastern Ghana, farmer managed natural regeneration (FMNR) using community labor was promoted in community regeneration sites. These sites were established on lands ceded by senior men from the villages' founding lineages, who retained privileged access to the products of trees growing on those lands as well as land management rights. As the sites were located near the homesteads of members of land allocating lineage, these households had easy access to their products. In this way, the land-allocating lineages benefited disproportionately from the community labor invested in FMNR. Moreover, a future risk is that land-allocating lineages would reclaim part of those lands for cultivation once soil fertility was enhanced as a result of FMNR. Asymmetries in access and control over land, which reflect unequal power relations among different lineages, gender, age, and livelihood groups, exacerbated the marginalization of certain social groups through restoration initiatives.

Given women's particularly tenuous rights to land (FAO 2005), market-based restoration and conservation models with benefit schemes tied to land ownership or relative contributions of land to restoration will have significant gender implications (e.g., see UN-REDD 2011, Pham 2016 on Payments for Ecosystem Services [PES]). As Kariuki and Birner (2021) show, even when land-and, consequently, PES revenue-is relatively evenly distributed among landowners (as in Kenya's Mara North Conservancy), women who are not sole heads of households may not be recognized as rightsholders, affecting both distributive and procedural equity. In this and other commodity-driven designs of conservation, profitmaking from conservation as production depends on the exploitation of unpaid subsistence household work (largely carried out by women) or on cheap, unwaged or free inputs and labor of the marginalized, including women (Collard and Dempsey 2020). In other words, gender inequality and social exclusions are not incidental, but rather "vital to the operations of capitalism" (Smith 2016). 
Political ecology analyses can offer further insight to the field of restoration by illuminating how power is exercised through the social construction of natural resources, environmental knowledge, and the discourses that frame and legitimize dominant knowledge claims (Forsyth and Walker 2008, Bassett and Peimer 2015). Scholars in the field demonstrate how knowledge that responds to the sociopolitical ethos of a given time develops, is stabilized, and circulates in environmental narratives (Fairhead and Leach 1996, Kull et al. 2015). Global environmental narratives tend to simplify complex socio-ecological processes and promote "particular notions of expertise; and particular sets of ideas about which social groups should carry the burden of blame and responsibility" (Forsyth and Walker 2008). In Kandel et al.s case study in Northeast Ghana (2021), blame is cast on Fulani pastoralists for creating bush fires, which simplistic narratives associate with impending degradation. Such narratives, which have buttressed fire suppression policies since colonial times, are remarkably persistent despite evidence of the value of anthropogenic fire regimes in ecological management processes (Laris 2002, Kull 2004).

In contemporary times, a diverse network of actors plays an important role in establishing the environmental "crises" narratives that justify politics of control and exclusion (Roe 1995, Scoones et al. 2015). These include the state and its various agencies (which do not always act in concert) as well as non-state actors, such as NGOs, international "experts" and researchers, civil society organizations, and the private sector; many of whom act at a distance from the ecologies to be restored. Questions around the production, circulation, and access to ecological knowledge become critical amid this panoply of actors (Gururani and Vandergeest 2014), who may have competing claims and interests centered on conservation, carbon sequestration, endangered species, land, livelihoods, and more (Mansourian 2021).

Central to these debates are the material and distributional implications of the co-production of environmental knowledge and governance of natural resources (Gururani and Vandergeest 2014, Stirling 2015), which can reinforce the marginalization of certain social groups (Kandel et al. 2021). As Scoones et al. (2015: 4) explain,

There is a politics around knowledge production [. . .], turning both on what we think we know (consensus and uncertainties) and on who knows it (whose knowledge counts). We must ask which scientist or other stakeholders, which forms of expertise, from the official to the informal, which disciplines and which regions have most voice in the construction of knowledge about the predicaments that underpin calls from green transformations. [. . .] Who sets the terms of debate [...] is crucial because organized knowledge, explicitly or implicitly, demarcates ways forward [and] suggests who can use which resources in order to live within environmental limits and planetary boundaries.

The power dynamics that authorize the knowledge of technical "experts" and particular ways of knowing the world as scientific and policy-relevant also discount the knowledge of resource users as "local" and lacking in credibility at higher (national or transnational) scales (Gururani and Vandergeest 2014). This is illustrated in Sen et al.s study (2021) of Bengaluru lakes, where the knowledge and management contributions of the traditional village water men, fishers, and pastoralists have been pushed aside with the ascendancy of engineers and bureaucrats. Universalizing discourses and the agendas they support thereby foreclose the creation of plural, nuanced paths to sustainability responsive to the realities, cultures, and priorities of diverse people and places (Stirling 2015). Political ecologists take a normative stance to open the discursive space to marginalized actors, such as local resource users, whose experience and knowledge have historically been omitted or undermined (Ribot 2007, Forsyth 2011, Bassett and Peimer 2015).

Lee et al.s paper (2021), which brings us to a remote archipelago in northern British Columbia, Canada, demonstrates how such a process can occur. Following a process fraught with conflict, contestation, and continuous efforts at reconciliation, the Haida First Nation are reasserting governance over Xaayda Gwaay (Haida Gwaii), their traditional territory. Under Indigenous leadership in a co-management agreement with the state, the ecological conservation and restoration of Xaayda Gwaay's coastal ecosystems are guided by Haida worldviews, ethics and values, and a combination of traditional and Western-scientific knowledge, which are considered with equal legitimacy. Respect, trust, and reciprocal learning among First Nations, federal agencies, academia, research institutes and the fishing industry-all of whom figure as co-authors in Lee et al's paper-are fostered through personal connections nurtured over collaborative work and shared meals. Such efforts, several decades old and on-going, are yielding fruit as "A foundation of Indigenous values provides a place to build rapprochement and a seed to start decolonizing ecological restoration and other conservation projects."

In posing the question "restoration for whom?", we examine who sets restoration agendas across scalesincluding at the global level, which frames national, subnational, and local ecological governance and initiatives, and authorizes constituent environmental knowledge and claims. As Lee et al. (2021) and standing debates within the field of restoration show, despite being justified as driven by science and fulfilling ecological imperatives, the goals of ecological restoration are not self-evident, but rather a matter of social values (Higgs 1994, Ehrenfeld 2000, Hobbs and Harris 2001, Swart et al. 2001). According to 
Davis and Slobodkin (2004a: 1), although "[r]estorationists have often tried to justify their goals by presenting them as fulfilling various ecological imperatives, e.g., restoring ecosystem health and restoring indigenous environments [...], characterizing communities and ecosystems as 'healthy' or 'damaged' is a value-based, not scientific, assessment."

Likewise, Barr and Sayer (2012: 2) argue that a) the "act of defining an area of forestland as 'degraded' is fundamentally a political act which shapes decisions regarding land-use and access"; the definition of degraded land can vary over time, even within a particular institution, and b) claims on so-called "degraded" lands scheduled for reforestation or conversion to plantations often underpin conflicts between the state and rural communities (see also Barney 2008).

The field of ecology becomes important when restoration is implemented, to achieve the stated ecological goals, but these goals fundamentally depend on the values placed on particular ecosystem states (i.e. the desirability of the system in the eye of the beholder) rather than on ecological principles (Hobbs 2004, Davis and Slobodkin 2004b). Distinct goals will reflect different values and priorities, engender different winners and losers, and require different policies and actions (Lackey 2004). In the case of Bengaluru's lakes, the livelihood values for agriculture, small-scale fishing, pastoralists, and collecting medicinal plants or flowers for worship have been pushed aside in favor of aesthetic and recreational benefits for first the British and then urban elites (Sen et al. 2021). The privatization of lakes and charging of entry fees is perhaps the most explicit example of commodification of ecosystem resources in this collection of cases.

If these goals are a matter of social values, whose values count in the agenda-setting process? As rights-based approaches prescribe, Amartya Sen's work on deliberative justice (2009) highlights that justice demands a fair say in defining the terms of debate. These terms include judgements about how knowledge is organized, such as how concepts such as "forests", "restoration", and "healthy ecosystems" are defined and mobilized, and what constitutes "success", "costs" or "benefits" in restoration. Yet, global environmental agendas, such as those based on forests and REDD+, tend to impart a homogenized, narrow, and topdown vision of what constitutes benefits and costs, how these should be distributed, and among whom (Forsyth and Sikor 2013). This is reflected in the Bonn Challenge's (2020) emphasis and measure of restoration success as increasing area under tree cover and carbon sequestration (e.g., the Bonn Barometer), with little attention to the socio-political and economic impacts of the global initiative.

In their article on restoration projects in Vietnam, McElwee and Nghi (2021) point out how Vietnam is, on paper, considered one of ten ecosystem restoration hotspots globally and exemplary for having committed to restoring 16 million hectares of forests. The country's ambitious agenda aims to enable individual households to control over 70 per cent of new forest plantations. However, in practice, Vietnam is failing not only on most social, but also ecological measures. Most restoration programs prioritize fast-growing tree species which have high commercial returns, yet the financial benefits from short rotation cycles for pulp and woodchip mills have poor ecological restoration potential. Moreover, despite programmatic intentions to reduce poverty and support smallholder livelihoods, because the focus is essentially on ensuring tree plantation targets, there is little attention to restoring social and political inequalities. Marginalized ethnic minorities tend to be ignored in favor of socio-economically better off households, who can be instrumental in "making projects work". In some cases, ethnic minorities slow to kick start these ambitious projects were compelled to sign off land use and harvesting rights to others (Thulstrup 2015 and Sandewall et al. 2010, cited in McElwee and Nghi 2021). There are multiple gender implications of these "greening projects", including women's losses from the replacement of diverse forest ecosystems by commercial tree species (see Elmhirst et al. 2017 for similar accounts of transforming "degraded" forests and diverse land uses of importance to women's livelihoods to monoculture oil palm with limited value for women).

Drawing on many types of knowledge in restoration, including traditional or local ecological knowledge, is prescribed in Principle 2 of the SER Standards (Gann et al. 2019). Yet, these Standards do not acknowledge the power-laden negotiations, contestations, reconciliations, and value judgements that such a process will entail. A political ecology approach can support greater engagement with the "politics of knowledge" (Jasanoff 2004, Goldman and Turner 2011), to meaningfully recognize and legitimize plural forms of knowledge, including those of resource users whose knowledge and experience have historically been silenced.

To conclude, restoration agendas and ecosystem governance profoundly affect lands, lives and livelihoods. Any critical step towards recognizing the rights of marginalized groups to democratic participation in these processes is incomplete without attention to the gendered nature of nature-society interrelations. However, FPE draws attention not just to complex, intersectional gendered inequalities, but equally, as we discuss below, to contextual, often nested and persisting histories of (neo)colonialism, patriarchy, and capitalism which create contradictions and tensions.

\section{Historical Awareness}

SER refers to restoration as the movement of a degraded ecosystem towards a healthier, reference ecosystem. In the SER Standards, reference ecosystems are to be established with attention to the ecological trajectory of the sites to 
be restored (Gann et al. 2019), and as such, there have been considerable efforts in the field to examine ecological histories. Yet, the Standards espouse a narrow and problematic understanding of historical knowledge against the rapid current pace of change. There has been longstanding debate over what this reference ecosystem should be in diverse contexts, considering the lack of historical records or baselines that afford a clear view of previous ecological states (Hobbs 2004, Higgs et al. 2014). Moreover, since humans have long been part of landscapes, "no community on Earth has escaped the direct or indirect effects of man" [sic], which begs the question: "which is the 'natural community' that one would seek to restore?" (Diamond 1985). If the amount of "degradation" perceived depends on the temporal and spatial boundaries against which baseline conditions are established (Bassett and Peimer 2015, Hull and Robertson 2000), who is to define those boundaries? As political ecologists caution, false assumptions about what is ecologically desirable, what was the previous ecology of a region, and the role of humans in degrading their environment can lead restoration policy and initiatives astray (Sigman and Elias 2021).

Whereas ecological history has received considerable attention in the field of restoration, the interlocking nature of ecological change and the socio-political histories that shape land degradation have received less so. Political ecologists argue, however, that historical events as well as the ways these are remembered and invoked in the present (i.e. "historical consciousness") (Moore 1993: 382) influence contemporary rights to resources and the values different actors place upon resource management (including restoration) options. These "remembered pasts", shifts in people's relationship to place and resources, and the historical influence of state policies on environmental management in the symbolic and material arenas (Moore 1993) consequently all hold relevance for how different actors engage with contemporary restoration initiatives. Kariuki and Birner (2021) trace the history of elite capture of benefits from privatization of group ranches before the establishment of the Mara North Conservancy in Kenya. In their study, men report that current benefit-sharing arrangements are more equitable, but half of the women do not report improvements, showing that history may not be experienced in the same way by all.

Of critical importance, ahistorical readings of lands as "wastelands", "barren" or "marginal", "empty" (of people), and sitting "idle" for restoration risks disenfranchising local people of the commons upon which they depend to gather wood and non-wood forest products, graze their animals, or pursue other livelihood activities. As noted above, a careful understanding of land use, claims, and customary and statutory tenure relations over time is critical to avoid displacement of marginalized groups and dispossession of their livelihoods, particularly as restoration is implemented in contexts with weak systems of governance, histories of land tenure conflicts and discrimination against women and Indigenous communities (Sarmiento Barletti and Larson 2017, Sijapati Basnett et al. 2017). In an influential exercise, the International Union for Conservation of Nature (IUCN), World Resources Institute (WRI) and University of Maryland identified more than two billion hectares of land with restoration potential globally based on aggregated data and geographic information systems; a number which has since been contested (Veldman et al. 2015). Such maps of areas suitable for restoration drawing on ahistorical biophysical data must be read with caution, as they can conceal the claims multiple actors may have on the lands to be restored and their importance for the livelihoods of resource-dependent peoples.

(Feminist) political ecology scholars have shown that an ahistorical reading of a landscape, couched in what may be scientifically questionable environmental narratives, can be used to advance political objectives of control over resources (Forsyth and Walker 2008, Jones 2008, Neumann 2008). For instance, the pioneering work of Fairhead and Leach $(1995,1996)$ revealed that unfounded narratives depicting population growth and the breakdown of community institutions as drivers of deforestation in Guinea contrasted with the history of forest-savanna mosaic vegetation in the region. This narrative justified the use of fines and imprisonment of local resource users to prevent "further" forest loss. Similarly, in Southeast Asia, narratives portraying local people as forest destroyers have been used to govern people and lands since colonial times, justifying the removal of local people from their lands or consolidating land under the purview of the state in the name of conservation and sustainability (Peluso 1992, Dove 1997, Li 2014). More recently, Baviskar (2020) explored the links between social privileges, urban geographies, and what counts as environmental issues in deeply unequal, socially segregated cities like Delhi in India, where the urban elite use the idea of protecting the environment to achieve goals that are essentially contrary to both ecological sustainability as well as social justice.

Sen et. al. (2021) write of similar middle-class aspirations for a lake in Bengaluru, India. Narratives about the lake reveal the aesthetic aspirations of the city's elite, which is against the fabric of ground realities of complexity, disparity, inequity and power imbalances. Sen et al. discuss how this is not just a new phenomenon. In India, social disparities have a historic origin - and the development of cities has been marred with exclusions of marginalized groups over time. The narratives presented in this paper show embodied experiences of blatant exclusions in urban green spaces, as a quote from a female cattle owner attests: "They have put a big fence around the lake. Do you know why? To keep people like us out. We don't look like you people, we don't dress like you all. They don't like us because of that. We come in dirty, torn clothes to cut some grass to feed our cows, but that big fence keeps us out." 
These examples point out that feminist political analyses-which look at the intersections of inequality and exclusion-need not always talk about women and natural resources. Powerful narratives such as those discussed above bear truth to questions around who decides what is restoration, why and how. They substantiate the feminist critique of the rampant expansion of "bourgeois environmentalism"-or the inherent contradictions between middle-class conservation agendas and esthetics and increasingly affluent middle-class lifestyles that lead to environmental degradation (Baviskar 2020). In this optic, feminist political ecology is not about how to engage women and other assumedly "homogeneous" groups of the vulnerable in restoration initiatives. It is essentially about rethinking what makes for "the environment" and what counts as "restoration", taking into account that these definitions of nature and nature-based solutions are steeped in "colonial modalities of power and propped up by imperial geopolitical and economic arrangements" (Collard et al. 2015, referencing Maldonado-Torres 2007). A feminist approach to sustainability entails breaking with exploitative histories through decolonizing knowledge frameworks, politics and ethics (Emel 1995, Collard et al. 2015).

\section{Scale Integration}

Identifying the drivers of degradation and sustainable, equitable alternatives requires understanding the ways higherorder political-economic processes influence resource use and management. Such efforts to position the proximate causes or symptoms of environmental change into their wider context are at the heart of political ecology (Bassett and Peimer 2015). For instance, in their seminal work on soil degradation and vegetation change, Blaikie and Brookfield (1987) consider how an "exogenous" political economy embeds the (generally rural) "land manager" or production unit's environmental behavior and marginalization. Unpacking this political economy using "chains of explanation", the authors link local environmental change with conditioning variables at the meso (land use practices) and macro (state and international economy) levels. This process of "progressive contextualization" (Vayda 1983) allows them to situate local environmental specificities in their historical and multi-scalar political economic contexts.

Despite their grassroots focus on local resource managers, political ecologists think across scales, from the global to the household and individual spheres. Scale integration efforts reveal how shifting socio-economic and political processes, norms and practices, and their constituent power relations, bear upon resource users' environmental management decisions and livelihoods (Zimmerer and Bassett 2003, Peet and Watts 2004, Robbins 2004, Walker 2005). Political ecology analyses are "location-specific, place-based and conjunctural" all the while integrating "non-place based relations" such as market and class relations (Emel and Peet 1989: 60, Tsing 2004).
Scale integration is a significant consideration in ecological restoration, although the focus lies in the relevance of scale for ecological processes. For instance, in the SER Standards, Principle 7 focuses on the gains that can be achieved when ecological restoration is applied at large scales as "many ecological processes function at landscape, watershed, and regional scales (e.g., gene flow, colonization, predation, ecological disturbances)" (Gann et al. 2019: S18, S20). Increasing the connectivity of floral and faunal populations through corridors by spatially linking restoration initiatives as well as implementing large-scale restoration initiatives, covering hundreds or thousands of hectares, is prescribed to achieve desired environmental and ecological goals. Integrated landscape planning is recommended to favor "net-positive landscape change" (Gann et al. 2019).

Yet, Mansourian's paper (2021) demonstrates that issues of scale in ecological restoration initiatives also comprise a critical socio-political dimension. Much of the attention to scale in landscape restoration has focused on administrative and biophysical units and how they are linked from the community to the national and even global scale (e.g., see the collection by Butler et al. 2019). Crossland et al. (2021) show the need to also look at the intrahousehold scale to understand the uptake of restoration efforts, as well as the distribution of related benefits. Pro forma consultation processes and negotiations apply at the farm and even plot level as well as at higher scales.

Mansourian's paper (2021) highlights that as one "jumps scale" from the local to the landscape scale, the number of actors with stakes in restoration multiplies. These actors may come from different sectors and disciplines, and may hold similar and synergistic, or distinct and conflicting goals and motivations for restoration. Embedded in unequal power relations, these actors have uneven abilities to negotiate, have their voices heard, and influence the direction of restoration initiatives. Political ecology scholars insist that scale is not only a product of biophysical processes, but also historically contingent and politically contested (Zimmerer 2006, Neumann 2009, Rangan and Kull 2009). Likewise, Mansourian (2021) argues that grounding restoration initiatives at the landscape scale raises questions around how physical boundaries should be established, and who is in and or out of a given landscape, and consequently of a given initiative. She argues for the need to examine (and at times, reconcile) the power-laden interrelations and perspectives of multiple actors in restoration processes.

In directing attention to the landscape scale, at which Forest Landscape Restoration initiatives are implemented, Mansourian's contribution raises questions such as: how do equity concerns manifest themselves as trade-offs emerge among a mosaic of land uses and users? Such questions call for renewed attention to relations of social marginalization and exclusion that often fall out of sight as the locus of analysis shifts beyond the local scale. For instance, 
gender research and praxis, including FPE, tend to focus on everyday and quotidian issues at the intrahousehold and community levels, with gender equity issues reducing in visibility as one goes up in scale. Yet, the everyday, quotidian element to decision-making among powerful actors acting at other scales (the state, corporate actors, and philanthro-capitalists) would be fertile ground for future FPE analyses of restoration.

Scale integration also demands attention to the way global interests and the global restoration agenda frame national, landscape-scale, and local restoration initiatives. Environmental crises narratives centered on climate change, land degradation, biodiversity loss, and transgressing planetary boundaries (Rockström et al. 2009, Lenton 2013) resound with a sense of urgency for a profound and "green" transformation (Scoones et al. 2015). In response to ecological imperatives, calls for coordinated global action and "earth system governance" (Biermann 2007) support the creation of centralized and uniform global policies and agendas (Forsyth and Sikor 2013, Scoones et al. 2015), such as those focused on restoration. As noted above, such calls are legitimizing new resource governance regimes, within which a range of actors and the multiple values they espouse, are gaining prominence (Chandhoke 2003, Adams et al. 2014, Kleinschmit et al. 2015). As the collection of papers in the special issue demonstrates, the rapidity and top-down manner with which these global environmental agendas develop can pose risks to democratic engagement in the process and can override messier issues related to inequity, social exclusion, and unequal power relations (Stirling 2015).

Feminist researchers would argue that the upcoming UN Decade of Ecosystem Restoration veers unwaveringly towards a "green development" agenda that see markets and corporations as the most appropriate vehicles to achieving a viable, sustainable conservation. It is highly questionable whether what "got [us] to this place of ruination and ecological impoverishment" can create conditions for alternatives (Collard et al. 2015: 2). FPE and other feminist approaches therefore ask for "pluriversal" rather than universal ways of knowing and doing and governance models that can break with historically exploitative economic relations that are inimical to nature, to create inclusive and sustainable political-economic alternatives (Escobar 2008, Collard et al. 2015).

\section{Conclusion}

The upcoming Decade for Ecosystem Restoration will likely result in a proliferation of restoration investments and interventions globally. This positive development calls for urgent attention to what has changed in our understanding of, and interventions to, restoring ecosystems. As noted earlier, the revised SER Standards offer a five-star system and "Social Benefits Wheel" to assess stakeholder engagement and inclusivity. Yet, these are presented as a "complement" to a five-star system and "Ecological Recovery Wheel", which takes center stage with defined biophysical measures of restoration success. These performance-based standards, inscribed in a technocratic approach to restoration, offer limited space for engaging with issues of power and justice as is needed for inclusive restoration. The chasm between feminist perspectives of environmental governance and mainstream restoration agendas remains deep and wide.

Higgs et al. (2018) argue that a "principles-first" approach that is contextual, evolving, and premised on engagement with communities can generate more meaningful space for communities to seek the restoration outcomes they desire. Building on this premise and following Mollet and Kepe $(2018,3)$, we underscore the need for such an approach to "name power in its multiple, intersecting and more than economic iterations" to avoid simplistic "solutions" to complex and deep-rooted problems. In this regard, we have argued that FPE can serve as an open and discursive approach to critically inform an understanding of power and politics and decolonize restoration science and practice. The issues examined in this special issue, framed within an FPE perspective here, provide three key lessons.

Firstly, there is critical need to examine the intersection of power, politics, and economic interests and mandates that drive restoration or "green" agendas. A convenient consensus between economic agendas and political interests has long underpinned development narratives and interventions (Mosse 2005). Political ecology scholarship has both critiqued and offered alternatives to "neoliberal environmentalism" by bringing attention to environmental injustices, the relational values and meanings of nature, and the incongruence between definitions of economic growth and human well-being (Swaffield 2016). Whether rural or urban, the environment is a contested arena, where fault lines of power, privilege, hierarchy and disparity merge to create uniquely embodied experiences of exclusion and inclusion (Swyngedouw and Kaika 2000). Lessons from diverse struggles, including racial justice, feminist movements, trans rights and expanded notions of identity, as well as decolonial FPE, show that environmental (in)justice is embedded in many intertwined layers of oppression. Achieving an inclusive sustainability through restoration will require challenging the systems of oppression that drive both environmental degradation and exclusion. To see ecosystem restoration as an apolitical, technical project or assume that economic rewards and gains can offset complex and mostly unequal contestations between the myriad needs, uses, values and meanings of the environment to diverse stakeholders goes against the transformative aims of the SDGs. As the case studies we have discussed show, such a narrow framing also fails to engender the desired change towards sustainable ecosystems.

The second lesson from our analyses is that what needs restoring is not simply a biophysical landscape, but a 
complex, dynamically changing space of socio-ecological interrelations. Restoration that ignores or erases local people's historical claims to land and resources, and the meanings they attribute to their landscapes, poses grave risks. As McElwee and Nghi's paper from Vietnam (2021) shows, we must critically approach claims that seeding fast-growing commercial tree species in landscapes that represent a historic and complex political and economic dispossession of local communities counts as restoration.

Finally, a global restoration agenda that lends itself to top-down policies and interventions can foreclose inclusive and democratic engagement in its governance. In asking "Who decides what is restoration and on behalf of whom?", we underscore the need to critically examine how and why restoration agendas and practices are framed across scales, and to legitimize the plural voices, values, situated knowledges, and paths to sustainably restoring degraded landscapes.

Feminist perspectives on natural resource management, which have unpacked and laid bare issues of inequality, power, patriarchy, and hierarchy in environmental agendas and outcomes, have yet to be espoused in restoration agendas, policies and plans (Yang et al. 2018). FPE perspectives provide the opportunity to analyze gender-power relations through a focus on embodied everyday experiences of degraded landscapes, as well as the historical, social, politi$\mathrm{cal}$, and economic contexts that anchor and structure issues of power and powerlessness (Colfer et al. 2018). Transforming degraded landscapes will require tackling not just the biophysical dimensions of the environment, but equally the systemic fault lines through which the environment is differently and unequally experienced by those whose marginality lies at the intersection of inequalities by gender, institutionalized power, and politics. Now is a momentous time to steer the restoration agenda towards "inclusive sustainability" (Leach et al. 2018) through policies and interventions which go well beyond just "re-peopling" restoration practices.

\section{Acknowledgments}

The authors thank Steven Handel, Editor in Chief, and Tabby Fenn, Assistant Editor, for supporting the publication of this special issue in Ecological Restoration. We gratefully acknowledge the valuable comments and suggestions of three anonymous reviewers on a previous version of this manuscript. Financial support for this work came from the CGIAR Research Programs on Forests, Trees and Agroforestry (FTA), Water, Land and Ecosystems (WLE), and Policies, Institutions, and Markets (PIM), as well as the Trust Fund Donors. This special issue builds upon a session on "Restoration by Whom, for Whom?" at the Society for Ecological Restoration's 8th World Conference on Ecological Restoration in Cape Town, South Africa.

\section{References}

Adams, W.M., I.D. Hodge and L. Sandbrook. 2014. New spaces for nature: The re-territorialisation of biodiversity conservation under neoliberalism in the UK. Transactions of the Institute of British Geographers 39:574-588.

Agarwal, B. 1997. "Bargaining" and gender relations: Within and beyond the household. Feminist Economics 3:1-51.

Barney, K. 2008. China and the production of forestlands in Lao PDR: A political ecology of transnational enclosure. Pages 91-107 in J. Nevins and N. Peluso (eds), Taking Southeast Asia to Market: Commodities, Nature, and People in the Neoliberal Age. Ithaca, NY: Cornell University Press.

Barr, C.M. and J.A. Sayer. 2012. The political economy of reforestation and forest restoration in Asia-Pacific: Critical issues for REDD+. Biological Conservation 154:9-19.

Bassett, T.J. and A.W. Peimer. 2015. Political ecological perspectives on socioecological relations. Natures, Sciences, Sociétés 2:157-165.

Baviskar, A. 2020. Uncivil Society: Ecology, Equity and the Commons in Delhi. New Delhi, India: Sage Yoda Press.

Bebbington, A., S. Guggenheim, E. Olson and M. Woolcock. 2004. Exploring social capital debates at the World Bank. The Journal of Development Studies 40:33-64.

Biermann, F. 2007. 'Earth system governance' as a crosscutting theme of global change research. Global Environmental Change 17:326-337.

Blaikie, P. and H. Brookfield. 1987. Land Degradation and Society. London, UK: Methuen.

Bonn Challenge. 2020. Forest Landscape Restoration (accessed 20 May 2020). www.bonnchallenge.org.

Bryant, R.L. 1998. Power, knowledge and political ecology in the third world: A review. Progress in Physical Geography 22:79-94.

Butler, W.H. and C.A. Schultz (eds). 2019. A New Era for Collaborative Forest Management: Policy and Practice Insights from the Collaborative Forest Landscape Restoration Program. London, UK: Earthscan/Routledge.

Carney, J. and M. Watts. 1990. Manufacturing dissent: Work, gender and the politics of meaning in a peasant society. Africa 60: 207-241.

Chandhoke, N. 2003. Governance and the pluralisation of the state: Implications for democratic citizenship. Economic and Political Weekly 38:2957-2968.

Chhatre, A., S. Lakhanpal, A.M. Larson, F. Nelson, H. Ojha and J. Rao. 2012. Social safeguards and co-benefits in REDD+: A review of the adjacent possible. Current Opinion in Environmental Sustainability 4:654-660.

Clement, F., W. Harcourt, D. Joshi and C. Sato. 2019. Feminist political ecologies of the commons and commoning. International Journal of the Commons 13:1-15.

Collard, R.C. and J. Dempsey. 2020. Two icebergs: Difference in feminist political economy. Environment and Planning A: Economy and Space 52:237-247.

Collard, R.C., J. Dempsey and J. Sundberg. 2015. A manifesto for abundant futures. Annals of the Association of American Geographers 105:322-330.

Colfer, C.J.P., B.S. Basnett and M. Ihalainen. 2018. Making Sense of 'Intersectionality': A Manual for Lovers of People and Forests (Occasional Paper 184). Bogor, Indonesia: CIFOR.

Cronkleton, P., Y. Artati, H. Baral, K. Paudyal, E. Birhane, H. Kassa et al. 2017. How do property rights reforms provide incentives for forest landscape restoration? Comparing evidence 
from Nepal, China and Ethiopia. International Forestry Review 19:8-23.

Crossland, M., A.M. Paez-Valencia, T. Pagella, C. Magaju, E. Kiura, L. Winowiecki et al. 2021. Onto the farm and into the household: Intrahousehold gender relations matter for scaling land restoration practices. Ecological Restoration 39:90-107.

Davis, M.A. and L.B. Slobodkin. 2004a. The science and values of restoration ecology. Restoration Ecology 12:1-3.

Davis, M.A. and L.B. Slobodkin. 2004b. Restoration ecology: The challenge of social values and expectations (Forum). Frontiers in Ecology and the Environment 2:44-45.

Diamond, J. 1985. How and why eroded ecosystems should be restored. Nature 313(6004):629-630.

Djenontin, I.N.S., S. Foli and L.C. Zulu. 2018. Revisiting the factors shaping outcomes for forest and landscape restoration in subSaharan Africa: A way forward for policy, practice and research. Sustainability 10:906.

Dove, M.R. 1997. The epistemology of Southeast Asia's anthropogenic grasslands: Issues of myth, science and development. Southeast Asian Studies 35:223-239.

Ehrenfeld, J.G. 2000. Defining the limits of restoration: the need for realistic goals. Restoration Ecology 8:2-9.

Elmhirst, R. 2011. Introducing new feminist political ecologies. Geoforum 42:129-132.

Elmhirst, R., M. Siscawati, B. Sijapati Basnett and D. Ekowati. 2017. Gender and generation in engagements with oil palm in East Kalimantan, Indonesia: Insights from feminist political ecology. The Journal of Peasant Studies 44:1135-1157.

Emel, J. and R. Peet. 1989. Resource management and natural hazards. Pages 49-76 in R. Peet and N. Thrift (eds), New Models in Geography: The Political-Economy Perspective. London, UK: Unwin Hyman.

Emel, J. 1995. Are you man enough, big and bad enough? Ecofeminism and wolf eradication in the USA. Environment and Planning D: Society and Space 13:707-734.

Escobar, A. 2008. Territories of Difference: Place, Movements, Life, Redes. Durham, NC: Duke University Press.

Fairhead, J. and M. Leach. 1995. Reading forest history backwards: The interaction of policy and local land use in Guinea's forestsavanna mosaic, 1893-1993. Environment and History 1:55-91.

Fairhead, J. and M. Leach. 1996. Misreading the African Landscape: Society and Ecology in a Forest-Savanna Mosaic. Cambridge, UK: Cambridge University Press.

Food and Agriculture Organization of the United Nations (FAO). 2005. The State of Food and Agriculture 2005. Rome, Italy: FAO.

Forsyth, T. 2003. Critical Political Ecology: The Politics of Environmental Science. London, UK and New York, NY: Routledge.

Forsyth, T. and A. Walker. 2008. Forest Guardians, Forest Destroyers: The Politics of Environmental Knowledge in Northern Thailand. Seattle, WA: University of Washington Press.

Forsyth, T. 2011. Politicizing environmental explanations: What can political ecology learn from sociology and philosophy of science?. Pages 31-46 in M. Goldman, P. Nadasdy and M. Turner (eds), Knowing Nature: Conversations at the Intersection of Political Ecology and Science Studies. Chicago, IL: University of Chicago Press.

Forsyth, T., and T. Sikor. 2013. Forests, development and the globalisation of justice. The Geographical Journal 179:114-121.

Gann, G.D., T. McDonald, B. Walder, J. Aronson, C.R. Nelson, J. Jonson et al. 2019. International principles and standards for the practice of ecological restoration. Restoration Ecology 27:S1-S46.
Goldman, M. and M.D. Turner. 2011. Introduction. Pages 1-23 in M.J. Goldman, P. Nadasdy and M.D. Turner (eds), Knowing Nature: Conversations at the Intersection of Political Ecology and Science Studies. Chicago, IL: University of Chicago Press.

Gururani, S. and P. Vandergeest. 2014. New frontiers of ecological knowledge: Co-producing knowledge and governance in Asia. Conservation and Society 12:343-351.

Haraway, D. 1991. Simians, Cyborgs and Women: The Reinvention of Nature. London, UK: Free Association Books.

Harcourt, W. and I.L. Nelson (eds). 2015. Practising Feminist Political Ecologies: Moving Beyond the 'Green Economy'. London, UK: Zed Books.

Harding, S. 1995. Just add women and stir?. Pages 295-307 in In Missing Links: Gender Equity in Science and Technology for Development. Gender Working Group, the United Nations Commission on Science and Technology for Development. ITDG Publishing, UNIFEM, Ottawa, Canada: IDRC.

Hecht, S. and A. Cockburn. 1989. The Fate of the Forest: Developers, Destroyers, and Defenders of the Amazon. London, UK: Verso.

Higgs, E. 1994. Expanding the scope of restoration ecology. Restoration Ecology 2:137-146.

Higgs, E. 2003. Nature by Design: People, Natural Process, and Ecological Restoration. Cambridge, MA: MIT Press.

Higgs, E., D.A. Falk, A. Guerrini, M. Hall, J. Harris, R.J. Hobbs et al. 2014. The changing role of history in restoration ecology. Frontiers in Ecology and the Environment 12:499-506.

Higgs, E., J. Harris, S. Murphy, K. Bowers, R. Hobbs, W. Jenkins et al. 2018. On principles and standards in ecological restoration. Restoration Ecology 26:399-403.

Hobbs, R.J. and J.A. Harris, 2001. Restoration ecology: Repairing the earth's ecosystems in the new millennium. Restoration Ecology 9:239-246.

Hobbs, R.J. 2004. Restoration ecology: The challenge of social values and expectations (Forum). Frontiers in Ecology and the Environment 2:43-44.

Hull, R.B. and D.P. Robertson. 2000. The language of nature matters: We need a more public ecology. Pages 97-118 in P.H. Gobster and R.B. Hull (eds), Restoring Nature: Perspectives from the Social Sciences and Humanities. Washington, DC: Island Press.

Jasanoff, S. (ed). 2004. The Co-Production of Science and Social Order. London, UK: Routledge.

Jones, S. 2008. Political ecology and land degradation: How does the land lie 21 years after Blaikie and Brookfield's Land Degradation and Society?. Geography Compass 2:671-694.

Kandel, M., G. Agaba, R.S. Alare, T Addoah and K. Schreckenberg. 2021. Assessing social equity in farmer-managed natural regeneration (FMNR): Findings from northeastern Ghana. Ecological Restoration 39:64-76.

Kariuki, J. and R. Birner. 2021. A conceptual framework for exploring equity in ecological restoration: The case of a market-based programme in Kenya. Ecological Restoration 39:77-89.

Khadka, M., S. Karki, B.S. Karky, R. Kotru and K.B. Darjee. 2014. Gender Equality Challenges to the REDD Initiative in Nepal. Mountain Research and Development 34:197-207.

Kleinschmit, D., B. Sijapati Basnett, A. Martin, N.D. Rai and C. Smith-Hall. 2015. Drivers of forests and tree-based systems for food security. Pages 87-110 in B. Vira, C. Wildburger and S. Mansourian (eds), Forests, Trees and Landscapes for Food Security and Nutrition. A Global Assessment Report, IUFRO World Series 33. Vienna, Austria: IUFRO.

Kull, C.A. 2004. Isle of Fire: The Political Ecology of Landscape Burning in Madagascar. Chicago, IL: The University of Chicago Press. 
Kull, C.A., X. Arnauld de Sartre and M. Castro-Larrañaga. 2015. The political ecology of ecosytem services. Geoforum 61:122-134.

Lackey, R.T. 2004. Restoration ecology: The challenge of social values and expectations (Forum). Frontiers in Ecology and the Environment 2:45-46.

Łapniewska, Z. 2016. Reading Elinor Ostrom through a gender perspective. Feminist Economics 22:129-151.

Laris, P. 2002. Burning the seasonal mosaic: Preventative burning strategies in the wooded savanna of southern Mali. Human Ecology 30:155-186.

Larson, A.M., T. Dokken, A.E. Duchelle, S. Atmadja, I.A.P. Resosudarmo, P. Cronkleton et al. 2015. The role of women in early REDD+ implementation: Lessons for future engagement. International Forestry Review 17:43-65.

Larson, A.M. and J. Springer. 2016. Recognition and Respect for Tenure Rights. Gland, Switzerland: International Union for Conservation of Nature and Natural Resources (IUCN).

Leach, M., B. Reyers, X. Bai, E.S. Brondizio, C. Cook, S. Diaz et al. 2018. Equity and sustainability in the Anthropocene: A socialecological systems perspective on their intertwined futures. Global Sustainability 1:1-13.

Lee, L.C., D. McNeill, P. Ridings, M. Featherstone, D.K. Okamoto, N.B. Spindel et al. 2021. Chiixuu Tll iinasdll: Indigenous ethics and values lead ecological restoration for people and place in Gwaii Haanas. Ecological Restoration 39:45-51.

Lenton, T.M. 2013. What early warning systems are there for environmental shocks?. Environmental Science and Policy 27:S60-S75.

Li, T.M. 2014. What is land? Assembling a resource for global investment. Transactions of the Institute of British Geographers 39:58-602.

Li, T.M. 2017. After Development: Surplus population and the politics of entitlement. Development and Change 48:1247-1261.

Light, A. 1994. Hegemony and democracy: How politics in restoration informs the politics of restoration. Restoration and Management Notes 12:140-144.

Light, A. and E.S. Higgs. 1996. The politics of ecological restoration. Environmental Ethics 18:227-247.

Lovo, S. 2016. Tenure insecurity and investment in soil conservation: Evidence from Malawi. World Development 78:219-229.

Maldonado-Torres, N. 2007. On the coloniality of being. Cultural Studies 21:240-270.

Mansourian, S. 2017. Governance and forest landscape restoration: A framework to support decision-making. Journal for Nature Conservation 37:21-30.

Mansourian, S. 2021. Disciplines, sectors, motivations and power relations in Forest Landscape Restoration. Ecological Restoration 39:pp-pp.

Martin, D.M. 2017. Ecological restoration should be redefined for the twenty-first century. Restoration Ecology 25:668-673.

McElwee, P. and T.H. Nghi. 2021. Assessing the social benefits of tree planting by smallholders in Vietnam: 2 lessons for large-scale restoration programs. Ecological Restoration 39:52-63.

McLain, R., S. Lawry, M.R. Guariguata and J. Reed. 2018. Toward a tenure-responsive approach to forest landscape restoration: A proposed tenure diagnostic for assessing restoration opportunities. Land Use Policy 80:1-12.

Mills, S. 1995. In Service of The Wild: Restoring and Reinhabiting Damaged Land. Boston, MA: Beacon Press.

Mollet, S. and T. Kepe. 2018. Introduction: Land rights, biodiversity conservation and justice: Rethinking parks and people. Pages 1-13 in S. Mollet and T. Kepe (eds) Land Rights, Biodiversity
Conservation and Justice Rethinking Parks and People. London, UK: Routledge.

Moore, D.S. 1993. Contesting terrain in Zimbabwe's eastern highlands: Political ecology, ethnography, and peasant resource struggles. Economic Geography 69:380-401.

Mosse, D. 2005. Cultivating Development: An Ethnography of Aid Policy and Practice. London, UK: Pluto Press.

Mukadasi, B. and M. Nabalegwa. 2007. Gender mainstreaming and community participation in plant resource conservation in Buzaya county, Kamuli district, Uganda. African Journal of Ecology 45:7-12.

Neumann, R.P. 2008. Probing the (in)compatibilities of social theory and policy relevance in Piers Blaikie's political ecology. Geoforum 39:728-735.

Neumann, R.P. 2009. Political ecology: Theorizing scale. Progress in Human Geography 33:398-406.

Osmani, S.R. 2010. Theory of justice for an imperfect world: Exploring Amartya Sen's idea of justice. Journal of Human Development Capabilities 11:599-607.

Peach Brown, H.C. 2011. Gender, climate change and REDD+ in the Congo Basin forests of Central Africa. International Forestry Review 13:163-176.

Peet, R. and M. Watts. 2004. Liberation Ecologies: Environment, Development and Social Movements. 2nd Edition. London, UK: Routledge.

Peluso, N.L. 1992. Rich Forests, Poor People: Resource Control and Resistance in Java. Berkeley, CA: University of California Press, Berkeley.

Pérez, D. and E. Ceccon. 2017. Ecological restoration in the socioenvironmental context of Latin America and the Caribbean. Pages 21-27 in E. Ceccon and D. Pérez (eds), Beyond Restoration Ecology: Social Perspectives in Latin America and the Caribbean. Buenos Aires, Argentina: Vázquez Mazzini Editores.

Perreault, T.A. 2003. Social capital, development, and indigenous politics in Ecuadorian Amazonia. Geographical Review 93:328-349.

Perry, J. 1994. Greening corporate environments: Authorship and politics in restoration. Restoration and Management Notes 12: 145-147.

Pham, T.T., Y.H. Mai, M. Moeliono and M. Brockhaus. 2016. Women's participation in REDD+ national decision-making in Vietnam. International Forestry Review 18:334-344.

Quisumbing, A.R. and N. Kumar. 2014. Climate-smart agricultural practices in rural Ethiopia: The gender-differentiated impact of land rights knowledge. Pages 43-46 in C. Ringler, A.R. Quisumbing, E. Bryan and R.S. Meinzen-Dick (eds), Enhancing Women's Assets to Manage Risk under Climate Change: Potential for Group-Based Approaches. Washington, DC: International Food Policy Research Institute (IFPRI).

Rangan, H. and C.A. Kull. 2009. What makes ecology political? Rethinking scale in political ecology. Progress in Human Geography 33:28-45.

Ribot, J. 2007. Institutional choice and recognition in the consolidation of local democracy. Democracy 50:43-49.

Robbins, P. 2004. Political Ecology: A Critical Introduction. New York, NY: Blackwell.

Rocheleau, D., B. Thomas-Slayter and E. Wangari. 1996. Gender and environment: A feminist political ecology perspective. Pages 3-23 in D. Rocheleau, B. Thomas-Slayter and E. Wangari (eds) Feminist Political Ecology: Global Issues and Local Experiences. New York, NY: Routledge.

Rocheleau, D.E. 2008. Political ecology in the key of policy: From chains of explanation to webs of relation. Geoforum 39:716-727. 
Rocheleau, D.E. 2015. A situated view of feminist political ecology from my networks, roots and territories. Pages 29-66 in W. Harcourt and I.L. Nelson (eds), Practising Feminist Political Ecologies: Moving Beyond the 'Green Economy'. London, UK: Zed Books.

Rockström, J., W. Steffen, K. Noone, Å. Persson, F.S. Chapin, III, E. Lambin et al. 2009. A safe operating space for humanity. Nature 461:472-475.

Roe, E. 1995. Except Africa: Postscript to a special section on development narratives. World Development 23:1065-1069.

Sandewall, M., B. Ohlsson, R.K. Sandewall and L.S. Viet. 2010. The expansion of farm-based plantation forestry in Vietnam. Ambio: A Journal of the Human Environment 39:567-579.

Sarmiento Barletti, J.P. and A.M. Larson. 2017. Rights abuse allegations in the context of REDD+ readiness and implementation: A preliminary review and proposal for moving forward. Infobrief 190. Bogor, Indonesia: Center for International Forestry Research (CIFOR).

Schroeder, R. 1999. Shady Practices. Berkeley, CA: University of California Press.

Scoones, I. 2016. The politics of sustainability and development. Annual Review of Environment and Resources 41:293-319.

Scoones, I., P. Newell and M. Leach. 2015. The politics of green transformations. Pages 1-24 in I. Scoones, M. Leach and P. Newell (eds), The Politics of Green Transformations. Oxon, UK and New York, NY: Routledge.

Sen, A.K. 2009. The Idea of Justice. Cambridge, Massachusetts: Harvard University Press.

Sen, A., H. Unnikrishnan and H. Nagendra. 2021. Restoration of urban water commons: Navigating social-ecological fault lines and inequities. Ecological Restoration 39:120-129.

SER (Society for Ecological Restoration) International Science and Policy Working Group. 2004. The SER international primer on ecological restoration. Version 2. Tucson, AZ: Society for Ecological Restoration.

Sigman, E. and M. Elias. 2021. Three Approaches to Restoration and Their Implications for Social Inclusion. Ecological Restoration 39:27-35.

Sijapati Basnett, B., M. Elias, M. Ihalainen and A.M Paez Valencia. 2017. Gender matters in forest landscape restoration: A framework for design and evaluation. Bogor, Indonesia: Center for International Forestry Research (CIFOR).

Smith, B.E. 2016. Life with mother and Marx: Work, gender, and class revisited (again). Environment and Planning A: Economy and Space 48:2085-2088.

Stirling, A. 2015. Emancipating transformations: From controlling 'the transition' to culturing plural radical progress. Pages 54-67 in I. Scoones, M. Leach and P. Newell (eds), The Politics of Green Transformations. New York, NY: Routledge.

Sundberg, J. 2017. Feminist political ecology: Sites of inspiration and formation. Pages 1-12 in: D. Richardson, N. Castree, M.F. Goodchild, A. Kobayashi, W. Liu, and R.A. Marston (eds) The International Encyclopedia of Geography. Hoboken, NJ: Wiley-Blackwell.

Swaffield, J. 2016. After a decade of critique: Neoliberal environmentalism, discourse analysis and the promotion of climateprotecting behaviour in the workplace. Geoforum 70:119-129.

Swart, J.A., H.J. Van Der Windt and J. Keulartz. 2001. Valuation of nature in conservation and restoration. Restoration Ecology 9:230-238.

Swyngedouw, E. and M. Kaika. 2000. The environment of the city or ... the urbanisation of nature. Pages 567-580 in G. Bridge and S. Watson (eds), A Companion to the City. Oxford, UK: Blackwell.
Tsing, A.L. 2004. Friction: An Ethnography of Global Connection. Princeton, New Jersey and Oxford, UK: Princeton University Press.

UNEP (United Nations Environment Programme). 2019. New UN Decade on Ecosystem Restoration to inspire bold UN Environment Assembly decisions (accessed 20 May 2020). www. unenvironment.org/news-and-stories/story/new-un-decadeecosystem-restoration-inspire-bold-un-environment-assembly.

UN-REDD. 2011. The Business Case for Mainstreaming Gender in REDD. Geneva, Switzerland: UN-REDD Program Secretariat.

Unruh, J.D. 2008. Carbon sequestration in Africa: The land tenure problem. Global Environmental Change 18:700-707.

Vayda, A.P. 1983. Progressive contextualization: Methods for research in human ecology. Human Ecology 11:265-281.

Veldman, J.W., G.E. Overbeck, D. Negreiros, G. Mahy, S. Le Stradic, G.W. Fernandes et al. 2015. Tyranny of trees in grassy biomes. Science 347(6221): 484-485.

Thulstrup, A.W. 2015. Livelihood resilience and adaptive capacity: Tracing changes in household access to capital in central Vietnam. World Development 74: 352-362.

Walker, P.A. 2005. Political ecology: Where is the ecology?. Progress in Human Geography 29:73-82.

Wilson, A. 2019. The Culture of Nature: North American Landscape from Disney to Exxon Valdez, Second Edition. Toronto, Canada: Between the Lines.

Yang, Y.C.E., S. Passarelli, R.J. Lovell and C. Ringler. 2018. Gendered perspectives of ecosystem services: A systematic review. Ecosystem Services 31:58-67.

Zimmerer, K.S. and T. Bassett. 2003. Approaching political ecology: Society, nature, and scale in human-environment studies. Pages 1-25 in K.S. Zimmerer and T. Bassett (eds), Political Ecology: An Integrative Approach to Geography and Environment Development Studies. New York, NY: The Guilford Press.

Zimmerer, K.S. 2003. Geographies of seed networks for food plants (potato, ulluco) and approaches to agrobiodiversity conservation in the Andean countries. Society \& Natural Resources 16:583-601.

Zimmerer, K.S. 2006. Cultural ecology: At the interface with political ecology-the new geographies of environmental conservation and globalization. Progress in Human Geography 30:63-78.

Marlène Elias (corresponding author), Alliance of Bioversity International and CIAT, Via dei Tre Denari, 472/a, 00054

Maccarese(Fiumicino), Italy, Marlene.elias@cgiar.org.

Deepa Joshi, International Water Management Institute (IWMI), Battaramulla, Sri Lanka.

Ruth Meinzen-Dick, International Food Policy Research Institute (IFPRI), Washington, DC, United States. 